\title{
Basis of Financial and Management Accounting Formation Within a Concession Company
}

\author{
Grafova T.O. \\ Rostov Branch of Russian Customs Academy \\ Rostov State Transport University \\ Rostov-on-Don, Russia \\ Grafova_to@donrta.ru
}

\author{
Tishchenko I.A. \\ Rostov State Transport University \\ Rostov-on-Don, Russia
}

\author{
Mishchenko O.A. \\ Russian Customs Academy \\ Rostov-on-Don, Russia
}

\begin{abstract}
The article presents the main types of concessions and their Russian application. The article covers the principal statements on financial and management accounting maintenance within a concession company. The importance of the accounting division into the financial and management ones is defined in the article. The article outlines the options for concessional assets disclosure in the accounts. The article compares two accounting models: an international model of financial accounting and a traditional financial accounting system. The international financial accounting model applicability for a concession company is concluded. The use of new management accounting tools is substantiated. The authors assume the accounting engineering tools to facilitate goals achievement and concessional assets analysis, valuation and management. Such tools can be represented by derivative balance sheets aimed at a company valuation, taking into account the influence of various external and internal factors.
\end{abstract}

Keywords-concession agreement; concession; accounting engineering tools; derivative balance sheet; international model; management accounting .

\section{INTRODUCTION}

Nowadays, many Russian economic branches are in stagnation, which indicates the lack of sufficient investment resources contributing to the prosperity of business and profit earning. Attracting a large number of Russian and foreign investors will enable Russian companies to reach a new production level, allowing the national economy to find new growth paths.

The relevance of the topic lies in a public-private partnership (PPP) being a mechanism to involve private investors in the state property development, promoting the construction of social and strategic facilities.

Varnavskiy V.G. states that "any given forms of cooperation between the state and the private sector have always existed. In the modern context, state participation is necessitated by the complex forms of performance management. At the same time, the institutional environment (legal and regulatory setting, management system, regulatory arrangements, etc.), in which PPP has been operating for the last 30 years, represents a new stage in the development of state-business relations" [2].

Nowadays, being one of the forms of PPP, a concession is hardly an open problem from an accounting and economic points of view, despite the fact that it is reflected in the works of many scientists.

The study of a concession as a contract type involved such scientists as S.A. Sosna, N.G. Doronina, V.G. Varnavskiy, O.N. Savinova [4, 9, 10]. The sphere of financial and management accounting of transactions under concession agreements engaged I.V. Palees, I.A. Tishchenko, T.O. Grafova [5, 8, 11].

In order to cover and study a given topic, the following tasks were set in the present work:

- To determine the existing types of concessions, and the ones applied in Russia.

- To compare the traditional and international financial accounting models and ground the one to be suitable for a concession activity.

- To suggest a concession facility management standard based on the use of accounting engineering tools.

The main point in the study of the topic under consideration is the absence of a current legislated basis, regulating the accounting procedure within a concession company. With the increasing number of Russian companies following a concessionary scheme in PPP during the last 10 years, this is a promising area for future considerations and recommendations on the financial and management accounting maintenance within a concession company. 
Tishchenko I.A. rightly points out in her work that The main goal of our research is to develop practical recommendations and proposals for the financial and management accounting of concession transactions.

In carrying out this scientific research, socio-economic phenomena were studied through the dialectic and functional methods together with the method of systems thinking. A method of enumeration and registration, tabulation procedure together with a discriminatory, structural-functional and comparative analysis were used to analyse the reference information.

\section{Research Methodology}

Sosna S.A. specifies that "the main feature of a concession agreement is that the contract relations objects (such as property and certain types of activities) are indivisibly and exclusively owned by only one of the parties to an agreement, namely the state or another governmental entity. The other party to the agreement is always represented by an individual liable for certain obligations in exchange for the rights granted to him" [9]. The existing concession types enable to find a balance between the counterparties' interests. There are the following concession types, divided into three sub-categories:

- Concession involving construction - BTO (Build, Transfer, Operate) "Building, Transfer, Management”, BOO (Build, Own, and Operate) "Building, Ownership, and Operation", BOOT (Build, Own, Operate, and Transfer) "Building, Ownership, Operation, and Transfer”, BOT (Build, Operate, and Transfer) "Building, Operation and Transfer", BLT (Build, Lease, and Transfer) "Building, Lease and Transfer”.

- Concession involving rehabilitation - ROT (Rehabilitate, Operate, and Transfer) "Rehabilitation (Reconstruction), Operation and Transfer”, RLT "Rehabilitation, Lease and Transfer" (Rehabilitate, Lease or Rent, and Transfer), BROT "Building, Rehabilitation (Reconstruction), Management, and Transfer (Build, Rehabilitate, Operate, and Transfer).

- Concession involving design - DB "Design and Building" (Design, and Build), DBO/DBM (Design, Build, and Operate/Maintain) "Design, Building and Operation/Maintenance", DBFO "Design, Building, Financing and Operation” (Design, Build, Finance and Operate).

In Russia, in accordance with the Federal Law dd. 21.07.2005 No. 115-FZ “On Concession Agreements”, only two types of concessions are used - BTO, in the infrastructure construction (roads, highways and airports building), and $\mathrm{DBO}$, in the social sphere, public utilities and power industry [1].

The existing legal framework to regulate enterprise accounting is reduced to the absence of standards and regulations for the accounting of concession agreement transactions. Currently, companies refer only to the bookkeeping and tax accounting explanations from the letters by the Ministry of Finance. "concession activity is a very promising direction, requiring the development of a systematic scientific and methodological basis of accounting to regulate it successfully [11]. The main approaches are as follows:

- Development of specialized statutory acts by the Ministry of Finance of the Russian Federation.

- Development of internal standards for business record under a concession agreement.

- Development of an operating chart of accounts within a concession company.

- Adding accounts/sub-accounts related to concession activities to the instructions on the chart of accounts use (Order of the Ministry of Finance of the Russian Federation dd. 31.10.2000 No. 94n)".

There are several opinions and scenarios regarding concessional assets disclosure in the accounts:

- Clause 16, Article 3 of the Federal Law No. 115 states: "A concession facility and other property transferred by a concedent to a concessioner under a concession agreement are disclosed in the concessioner's balance sheet and ringfenced from its property. Regarding these facility and property, the concessioner maintains independent records, adhering to the obligations under the concession agreement, with an accrual of depreciation of these facility and property being made. Hence, the law provides for the disclosure of the concession facilities in an off-balance account, disclosing the data in a separate balance sheet, which is a combination of cost parameters related to the use (operation) of the concession facility (Letter No. 0705-06/324)."

- The disclosure of concession facilities in balance accounts, with special sub-accounts and analytical items being allocated, and adding into the concessioner's overall balance with explanations provided in the balance sheet supplement (for example, bookkeeping entries, Debit side 01/Concession Facility for transfer to the concedent - Credit side 08/building (reconstruction) Concession Facility - concession facility entered into the books, ready for transfer to the concedent; Debit side 02/Depreciation Concession Facility-Credit side 01/Concession Facility).

- Palees I.V. suggests "to disclose concession facilities on a designated account 06 "Concessional asset” [8].

The following separate sub-accounts, opened to account 06 "Concessional assets", are suggested to be used for analytic asset accounting of various concessional assets:

- 06.1 "Infrastructure.

- 06.2 “The exclusive right of a concessioner”.

- 06.3 "Government's liability for compensations."

As far as we are concerned, the disclosure of concession facilities in the balance sheet asset base, provided with 
- Financial accounting optics application (production, financial, mixed). method of concessional assets accounting, since this asset type meets all the requirements for being recognised as such, according to PBU (Accounting Regulation) 06/01 "Assets Accounting" and PBU 14/2007 "Intangible asset accounting", often being the main source of profit for the concessioner.

\section{RESULTS}

A concession company draws up financial reports, basing on indicators generated in production costs, administrative and selling expenses. Such information disclosed in the accounting financial reporting will be sufficient for external users.

Management accounting, on the contrary, is a company's internal accounting and, being a commercial secret, is intended for a narrow circle of users. Being more extensive and analytical, management accounting requires a detailed disclosure of the expenditures in the accounts.

In foreign practice, a company's financial and management accounting are maintained separately. Financial accounting is formed using the 30s accounts, while management accounting is disclosed in the 20s accounts. Due to this, the financial reporting is not commercially confidential, since the 30s accounts are the ones of the financial result, where all the provisions are charged off, while the adjustments are made by regulating unfinished production and provisions. This model is called international and has several advantages over the traditional one used by most Russian companies:

- Using the gross method in the elements' cost accounting, with the cost being determined by the goods produced and sold, and the costs are adjusted to change all the manufacturing resources.

- It provides for the financial result determined by an elementary-oriented approach based on a discrete or perpetual inventory.

- Tax accounting integration into financial accounting.

- The elements' cost accounting (tangible costs, labor costs, welfare payments, depreciation, miscellaneous expenses, costs submission, the elements' cost accounting disclosure, manufacturing resources balance).

The traditional accounting system is not able to fully provide external and internal users with the sufficient amount of information that would meet their needs and allow them to make justified and timely managerial and policy decisions to result in profit maximization.

An important advantage of using the international model within a concession company is the accounting involving the use of new tools in financial, management and strategic accounting:
- Structured accounting scheme scheduling.

- Application of accounting engineering tools (derivative balance sheets).

- Usage of aggregate bokkeeping entries and hypothetical processes.

- Project milestones.

The application of the international model within a concession company is based on the structured accounting scheme scheduling. Based on the modular architectonics and accounting engineering tools, such an accounting scheme enables to create the most reliable and efficient data in an accessible and detailed form, providing the analytics and division by the type of activity within the financial, management and strategic accounting.

Tishchenko I.A. states the following: "In recent years, management accounting has become more and more firmly settled in the common accounting system in companies, implementing its methodology based on the economy study mainstays (measurement and estimating), accounting methods (information accumulation and processing) together with administrative management (planning and control)" [11].

Companies are increasingly interested in the management accounting tools that, providing effective methods, allow companies to analyze, evaluate, manage and identify inefficient activities and achieve their goals.

In our opinion, such tools are the accounting engineering ones, aimed at:

- The exchange relations regulation and decision making under risk and uncertainty.

- Application of aggregated and disaggregated property indicators (net assets and net liabilities).

- Creation of accounting and analytical system.

- Risk envelope management.

- Application as an adequate valuation measurement system (book, market and fair valuations).

Accounting engineering tools will enable to solve complex tasks arising during concession transactions, to optimize concession accounting, and identify weak points in concession activities. In her work Tishchenko I.A. developed a concession facilities management accounting standard based on the accounting engineering tools (Table 1). 

TOOLS [3]

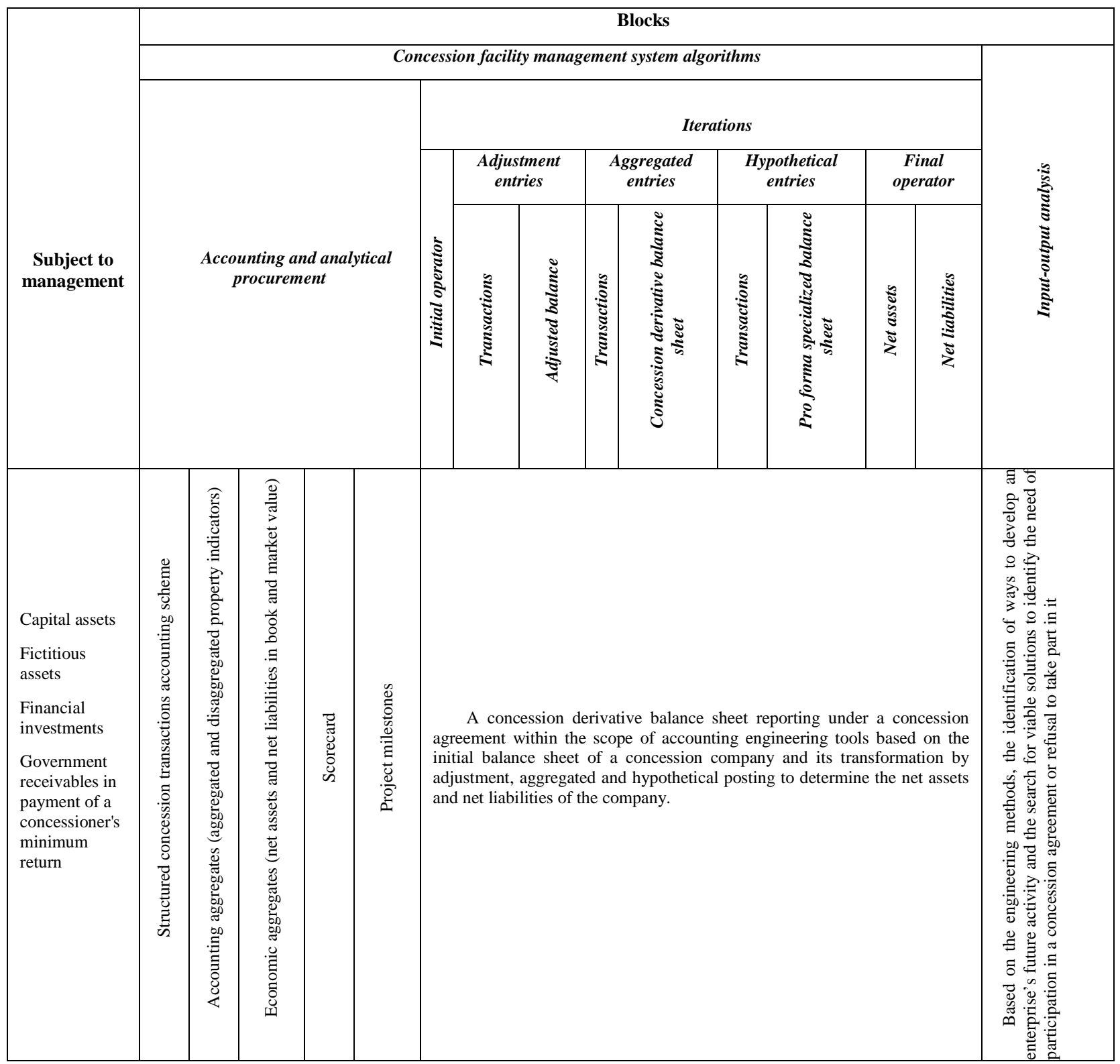

The mainstays of engineering methods within a concession company are the following:

- interconnection between the initial operators and the existing management system;

- interrelation with the information system (planning, accounting, payment and settlement one);
- pplication of aggregated indicators as the initial operator to draw up a concession derivative balance sheet.

Based on a complex of computer programs patented by their authors, a concession company is proposed to use the accounting engineering tools as represented by reporting a concession derivative balance sheet. The balance sheet will enable to determine the financial risk areas for each 
[15] Alexsandr S. Kuznetsov. Russian Professor's meeting. Russian Journal of Physical Education and Sport. 2019, 14(1), pp. 17-22. DOI: 10.14526/2070-4798-2019-14-1-18-

\section{References}

[1] Federalnii zakon ot 21.07.2005 № 115-FZ «O koncessionnih soglasheniah». Federal law of 21.07.2005 №115-FZ " on concession agreements». //http://www.consultant.ru/document/cons_doc_LAW_54572/

[2] Varnavskii V.G. 2011. Public-private partnership: some issues of theory and practice. Mirovaya economika v mejdynarodnih otnosheniyah. 2011, 9, pp. 41-60.

[3] Delmon J. Private Sector Investment in Infrastructure. 2-nd Ed. A Copublication of the World Bank and Kluwer Law International, The Netherlands-2009.

[4] Doronina N. G. research Topic-concession agreements / / Journal of Russian law. 2002. No. 9. pp. 168.

[5] Grafova, T. O. organization of transaction management accounting operations on concession agreements [Text] / T. O. Grafova, I. A. Tishchenko / / Science and education: economy and Economics; entrepreneurship; law and management. - 2015.

[6] Kulakova N. G., development of accounting and analytical support of innovative potential of the organization: dissertation ... candidate of economic Sciences, Pskov, 2010, 199 p.

[7] Lileeva L. R., Financial, managerial, strategic accounting in organizations of communication and telecommunications: theory and practice. Rostov-on-don; Russian state social University, 190 p.

[8] Palees I. V. Accounting of operations under concession agreements. Candidate's thesis. St. Petersburg.

[9] Savinova O. N. Legal nature of the concession contract / O. N. Savinova// Russia: ways of development in the XXI century: Materials of the final scientific and practical conference of the faculty of the Ieuip (Kazan). 3 h. h. 2. - Kazan: Taglimat Publishing house of the Institute of Economics, management and law, 2004. - pp. 114-116.

[10] Sosna S.A. Concession agreement. Theory and practice, 2002, pp. 2728.

[11] Tishchenko I.A. Formation of a system of accounting for operations under concession agreements with the concessionaire. Candidate's thesis. Orel: Orel state University. I. S. Turgenev. 2017.

[12] V. I. Tkach, G. E. Krokhicheva system of zero derivative balance sheets and their use in management, management Issues, 12, 2004

[13] Yescomb E. R., Principles of project financing-Moscow: Vershina, 2008

[14] Zimakova L. A., Development of theory and methodology of formation of accounting systems on the basis of international models of financial accounting and control: dissertation ... doctor of economic Sciences, 2009. - $414 \mathrm{~s}$ 